\title{
Mary Medusa
}

\section{Shawna Dempsey and Lori Millan}

Dans la mythologie grecque, le pouvoir de Méduse de transformer les hommes en pierre subsiste, même après sa décapitation par Persée. En plaçant la tête de Méduse sur son bouclier, Persée s'appropria le pouvoir de Méduse. Les éléments du mythe de Méduse (violence, appropriation et pouvoir) sont au centre de l'oeuvre Marie Méduse des collaboratrices Shawna Dempsey et Lori Millan, une performance féministe basée sur le costume. Les photographies de l'oeuvre représentent la tête de Méduse servie sur un plateau, sa bouche obstruée et réduite au silence, Méduse en mariée, attendrissant un morceau de viande avec le talon de son soulier, et la tête de Méduse sur un pilier grec. À travers performance, costumes, et diapositives projetées sur la scène, Dempsey questionne le fondement de plusieurs stéréotypes et archétypes féminins qui ont leurs racines dans la chrétienneté, la théorie freudienne, et la mythologie de l'ancienne Grèce. Dans son essai, Lynda Hall étudie quelques scènes-clés de Marie Méduse, refléchissant à la façon dont Dempsey établit son corps performant comme un texte, et à la façon dont elle utilise son corps pour intervenir dans les schèmes culturels patriarcaux pour offrir l'alternative d'une économie $d u$ désir. Comment le pouvoir est-il écrit (inscrit) sur le corps, demande Hall? Comment la performance féministe propose-t-elle des stratégies pour lire et écrire le corps de la femme? 


\section{Excepts from performance text by Shawna Dempsey and Lori Millan}

(Medusa/bride tenderizes meat she has removed from her jewel box, using the heel of her shoe as a utensil.)

Cooking is a lot like murder.

The pre-meditated variety.

You prepare, execute, and consume the rewards.

Not that I have tons of experience with either one.

I mean, I'm no gourmet.

But I know what I like.

And what I don't like.

Of course murder is also a lot like sex.

It's sort of a cliché, isn't it, that cumming is a petite morte.

But I'm not talking about death due to natural causes.

I'm talking about shoot-to-kill murder.

Having the power to push someone into oblivion.

Not unlike...

Sex.

I guess you could say sex is a lot like cooking.

People are always saying:

Sex is like driving a fast car.

Sex is like catching a big fish.

Sex is like chocolate cake.

But it isn't.

Sex is like murder.

But not in a bad way!

(decapitated head of Medusa)

Now this is a secret. My body holds my autobiography. All that I have suffered and longed for is stored beneath the skin. Written down carefully on my back and thighs and hands, my story is written on my flesh. And yet my flesh is a stranger to me. I look and I look and I can't find it anywhere. My self is missing. And I miss myself. Terribly. 

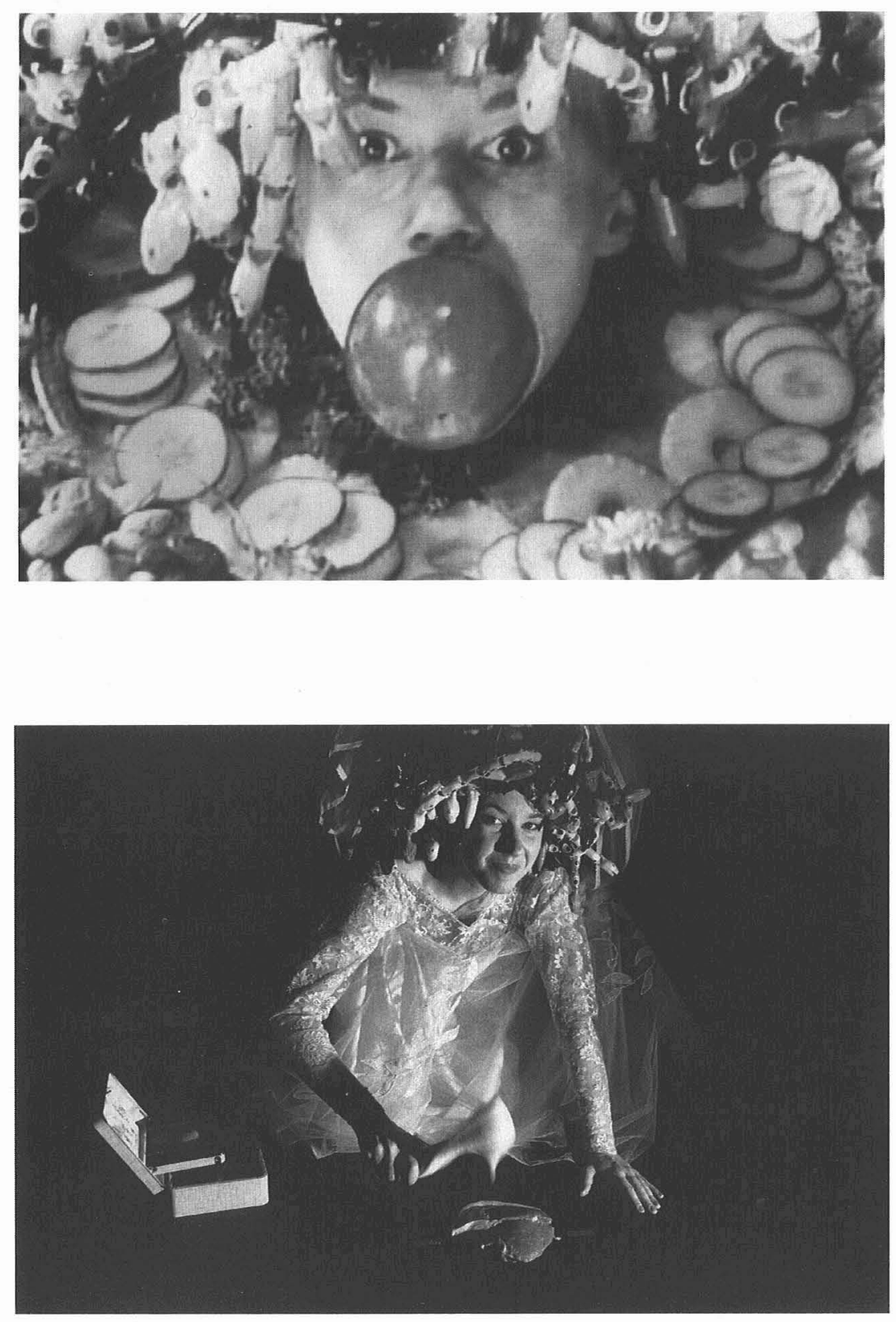